\title{
Concentration After the Nth Dose
}

National Cancer Institute

\section{Source}

National Cancer Institute. Concentration After the Nth Dose. NCI Thesaurus. Code C92378.

The concentration at the Nth dose. 